\title{
A NEW LOCALITY OF ENDANGERED BOG BULRUSH SCHOENOPLECTIELLA MUCRONATA (CYPERACEAE) IN THE EASTERN POLAND
}

\author{
Michą Rybak, Maciej GąbKa,Wojciech PęczuŁA
}

\begin{abstract}
M. Rybak, Department of Water Protection, Institute of Environmental Biology, Faculty of Biology, Adam Mickiewicz University, Umultowska 89, 61-614 Poznań, Poland, e-mail: m.rybak@amu.edu.pl

M. Gąbka, Department of Hydrobiology, Institute of Environmental Biology, Faculty of Biology, Adam Mickiewicz University, Umultowska 89, 61-614 Poznań, Poland, e-mail: gmaciej@amu.edu.pl

W. Pęczuła, Department of Hydrobiology, University of Life Sciences in Lublin, Dobrzańskiego 37, 20-262 Lublin, Poland, e-mail: wojciech.peczula@up.lublin.pl
\end{abstract}

(Received: September 30, 2015. Accepted: November 30, 2015)

\begin{abstract}
AвSTRAct. A new locality of Schoenoplectiella mucronata - an endangered and warm-temperature wetland species was found in Western Polesie (Eastern Poland). The new station is situated far away to the north-east from all known Polish sites and belongs to the easternmost one within European range of the species. The mesotrophic Lake Kleszczów in which we have found a new population of $S$. mucronata was characterised by a good ecological state as well as high diversity of aquatic plants dominated by a charophyte meadow. The studied species occurred in a phytocoenosis which is similar to a not known in Poland plant community Typho angustifoliae-Schoenoplectetum mucronati described from Hungary.
\end{abstract}

KEY WORDS: Schoenoplectiella mucronata, distribution range, threatened species, habitat conditions, Chara-lakes

\section{INTRODUCTION}

Schoenoplectiella mucronata (L.) J. Jung \& H.K. Choi (name by revision of JUNG \& CHOI 2010; syn. Schoenoplectus mucronatus L. Palla ex. A. Kern, Scirpus mucronatus L.) is a perennial species growing in wetlands (swamps and marshes), ponds and shallow lake coastal zones (ŻUKOWSKI 1969). It is a warm temperature species which natively occurs in tropical and sub-tropical areas of Eurasia, Australia and Polynesia (Hultén 1958, Casper \& Krausch 1980, Brink 2011). It was also introduced to North America, where became a nuisance weed of rice fields and other crops (FIsCher et al. 2010, BrinK 2011, LANSDOWn 2013). In Europe it was mainly noted in the Mediterranean area and rarely in the central part of the continent (Meusel et al. 1965, DeBerRy et al. 2010, Jung \& Choi 2010). Polish localities of $S$. mucronata are regarded as the northernmost one within European range of this species (Meusel et al. 1965, ŻuKowsKi 1969, DeBERRY et al. 2010).
Ten localities of Schoenoplectiella mucronata were described during the last century in Poland. Nowadays five of them are confirmed. All known sites (current and historical) are located in south-western Poland. The main concentration of its stations is situated in the Oświęcim Basin, in fishponds located in a short distance from each other: in Bronowo (ZAJĄC 1989), in Brzeszcze ponds (Rozmus 1974, KaźmierczaKowa et al. 2014), in Poręba Wielka (Banaś 2001, KRUK \& SZYMAŃSKA 2011) and in Skotnica (KAŹMIERCZAKOWA et al. 2014). More distant from them is S. mucronata station in pond in Kobiernice Górne (circa $10 \mathrm{~km}$ from Bielsko-Biała) in Silesian Upland (KотоŃsKA 1991). The majority of historical stations in Poland are located far away to the north from those currently confirmed. This species was noted in Radziądz (Schube 1903) and Rawicz (Żukowski 1969) in the southern Greater Poland Lowland. Moreover it occurred in Wierzbica Górna in the Silesian Lowland, in Żeleźnik in the Sudetes Foreland (Schalow 1930) 
and in Chybie near Goczałkowice reservoir (SCHUBE 1903), where it was noted until 1974 (Rozmus 1974).

Schoenoplectiella mucronata is considered as strongly threatened species in many European countries. In Poland and Austria it has a conservation status of endangered (EN), in Croatia as critically endangered (CR), while in Czech Republic is regarded as extinct species (EX) (Nikolić \& Topić 2005, Zarzycki \& Szeląg 2006, KAŹMIERCZAKOWA et al. 2014). The species is listed in the IUCN Red List of Threatened Species as well as in the European Red List of Vascular Plants (Bilz et al. 2011, Lansdown 2013, KaźmierczaKowa et al. 2014). Due to its rarity and the high risk of endangerment, S. mucronata became a protected species in Poland in 2014 (RozPoRZĄDZENIE... Dz.U. 2014, poz. 1409).

The new locality of the species was found during field studies in the Western Polesie (Eastern Poland) region in 2013. As the site is situated far away of its known European range we intended to give a short note about a new locality of this rare and endangered species. This paper provides also an overview on: (1) the habitat conditions and (2) plant species composition in the aspect of phytosociology of the studied locality of S. mucronata.

\section{DESCRIPTION OF THE NEW STATION}

The new locality of Schoenoplectiella mucronata was found in the litoral zone of Kleszczów Lake in 2013. This lake is situated in the central-eastern part of the Western Polesie (in the mesoregion of the Łęczna-Włodawa Plain), in the territory of Uścimów community, about $40 \mathrm{~km}$ to NE from Lublin (Lublin Province; Fig. 1), in the ATPOL grid square GD-90 (ZajĄC \& Zając 2001).

Lake Kleszczów is a shallow (max. depth $3 \mathrm{~m}$ ), small $\left(0.54 \mathrm{~km}^{2}\right)$, and polymictic water body. Its di- rect catchment is of $2 \mathrm{~km}^{2}$ area and comprises mainly of forests and agricultural lands. There is a small amount of dispersed buildings of a resort character, without compact farm buildings or any industrial factories. The lake is surrounded by a pine forest from the north and the north-east, arable lands are located on the eastern and western sides, whereas transitional bogs (poor fens), currently used as pastures are located to the south from the lake shore. The lake is connected with two ditches which were constructed during drainage works in the $20^{\text {th }}$ century and they connect the lake to the Piwonia River and an eutrophic Lake Miejskie. Both watercourses are shallow and overgrown, thus there is no water flow nowadays (KorNijów, unpublished data).

Lake Kleszczów is situated in the protected areas: "Ostoja Parczewska" PLH060107, "Lasy Parczewskie" PLB060006 as well as "Łęczna Lake District Landscape Park".

\section{MATERIAL AND METHODS}

The field study was conducted in September 2013. A phytosociological relevé in the studied locality was made using the classical Braun-Blanquet method (DierschKe 1994). Electrolytic conductivity and $\mathrm{pH}$ were measured directly in the field using a multiparameter-probe device (YSI 556 MPS). The nomenclature of vascular plant species was given after MiREK et al. (2002). The names of plant communities were adopted after RATYŃSKA et al. (2010).

\section{RESULTS AND DISSCUSION}

A new population of Schoenoplectiella mucronata was found near the shore of the eastern part of Lake Kleszczów (Fig. 1). The lake vegetation was dominat-

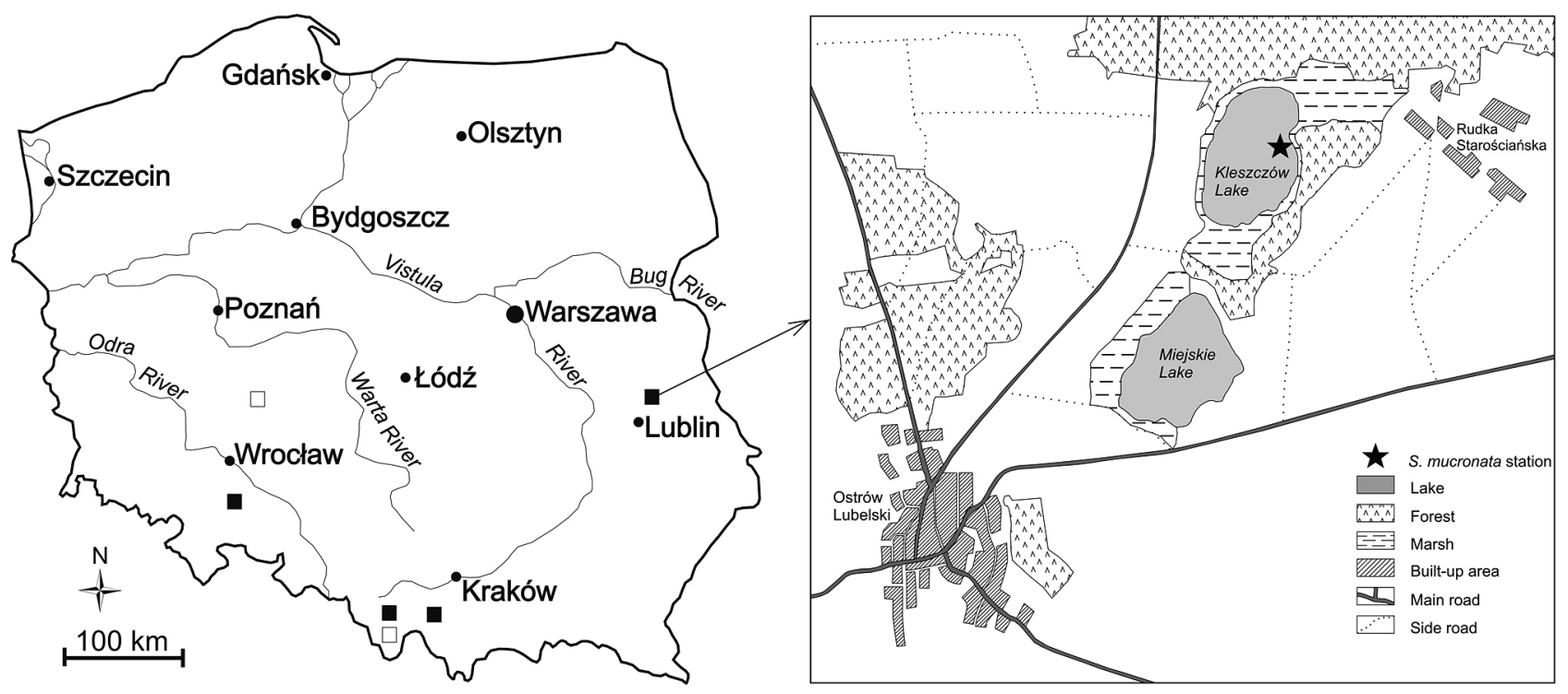

Fig. 1. Location of a historical $[\square]$, present $[\square]$ and new locality of Schoenoplectiella mucronata in Poland and in the Lake Kleszczów 
ed by a charophyte meadow (Charetum delicatulae Doll 1989 ex Gąbka et Owsianny 2010). Other plant communities which were found in the lake consisted of Nymphaeetum albo-candidae (Hejny 1950) Pass. 1957, Myriophylletum alterniflori Lemée 1937 and Potametum graminei (W. Koch 1926) Pass. 1964. There is also a broad belt of emergent macrophytes, overgrown mainly by Typha angustifolia.

Tussocks of $S$. mucronata appeared in the vegetation-free littoral zone at the depth of $0.2 \mathrm{~m}$ (Fig. 2 ). The shallow muddy shore in this site was overgrown by Ranunculo-Juncetum bulbosi Oberd. 1957 and a charophyte meadow. Schoenoplectiella mucronata presence was documented with a phytosociological relevé: date -25.09 .2013 , area $-12 \mathrm{~m}^{2}$, cover $-60 \%$, species composition: Schoenoplectiella mucronata 3.3, Myriophyllum alterniflorum 2.2, Chara virgata 1.1, Typha angustifolia 1.1, Potamogeton gramineus + , Carex rostrata + .

The newly found site of $S$. mucronata is characterised by a high diversity of aquatic plants. However, until now, bog bulrush was disclosed in Poland only in a pioneer plant communities of the class Litorelletea uniflorae with Pilularia globulifera (SzCZĘŚNIAK et al. 2012). What is interesting, documented phytocoenosis from Lake Kleszczów is similar rather to a rich in species plant community described from Hungary (not documented yet in Poland) - Typho angustifoliae-Schoenoplectetum mucronati (Ubrizsy 1961) Borhidi 2003. Stoneworts and other macroalgae were frequently reported in phytocoenoses of this association (BorHIDI 2003).

The newly found locality of $S$. mucronata determines a new eastern range of this species and belongs to the easternmost one within European range of the species. The origin of this newly found population is difficult to determine. This locality can be considered as an example of a spontaneous spread or a population regeneration. A similar character of the occurrence but related to thermal conditions was pointed in papers from Germany (CASPER \& KRAUSCH 1980, DeBerry et al. 2010). In our study the population occupies an ephemeral habitat, which suggests that the species tolerates moderate disturbance.

In Poland S. mucronata usually covers muddy banks of ponds, wetlands and wet meadows (ŻuKowsKi 1969). It was observed in pond shores, in a shallow littoral as well as in wetland stations in fishponds where water occurs only in the spring (ŻuKOwsKI 1969, Rozmus 1974). It was demonstrated that the species prefers nutrient-rich waters (DeBerRY et al. 2010, FIsCher et al. 2010) which states in a contradiction with our research. The water in Lake Kleszczów was characterised by low electrolytic conductivity $\left(120 \mu \mathrm{S} \mathrm{cm}^{-1}\right)$ and slightly alkaline $\mathrm{pH}$ (8.2). The lake has been in good trophic (mesotrophic) and ecological state since about 30 years (KoRNijów, unpublished

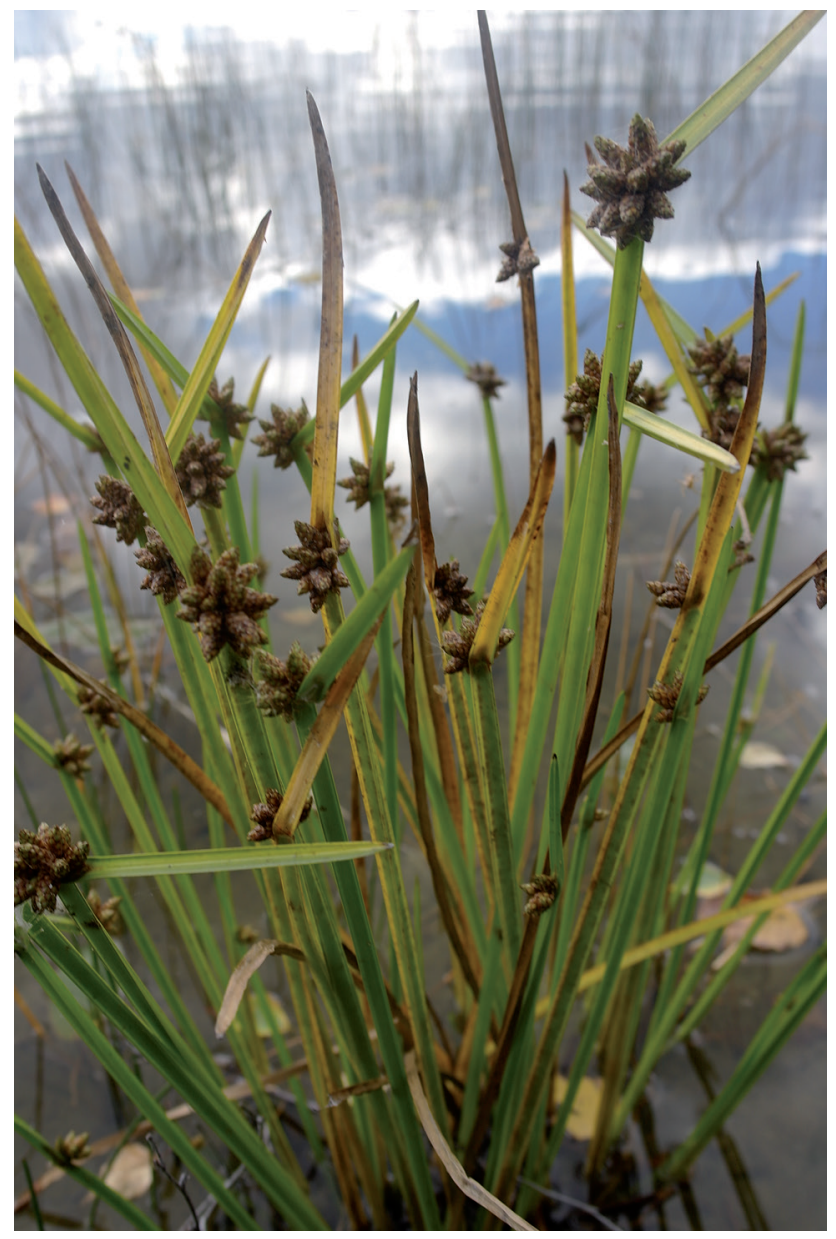

Fig. 2. The tussock of Schoenoplectiella mucronata in the new locality

data). Nutrients concentration at the beginning of the $21^{\text {st }}$ century was low $\left(\mathrm{TP}=0.026-0.038 \mathrm{mg} \mathrm{dm}^{-3}\right.$, $\mathrm{TN}=1.020-1.130 \mathrm{mg} \mathrm{dm}^{-3}$ ) (KoRNijów et al. 2002), and they were even lower in the summer of 2010 (TP $=0.015-0.022 \mathrm{mg} \mathrm{dm}^{-3}, \mathrm{TN}=0.683-0.728 \mathrm{mg} \mathrm{dm}^{-3}$ ) (TARKOWSKA-KUKURYK, unpublished data). However, a brown bullhead (Ameiurus nebulosus Lesueur, 1819) population has been noted in the lake for several years. This is an invasive species which is currently present in many lakes of Western Polesie (Kornijów et al. 2003).

In Poland S. mucronata is recognized as a species threatened with extinction, due to the limited number of stations and a very small population (KaźMIERCZAKOWA et al. 2014). An additional threat is habitat loss as a result of drainage works, a reclaim of wetlands and economic treatments in reservoirs. The current knowledge about the species suggests that S. mucronata is very sensitive to droughts, while is very tolerant to flooding (FIsCHer et al. 2010). An accurate monitoring of the eastern Poland S. mucronata population as well as a determination of its dynamic trends and a potential ability to a spread within the Western Polesie area are strongly recommended. 


\section{ACKNOWLEDGMENTS}

The study was supported in part by the statutory activity of the Department of Hydrobiology at Adam Mickiewicz University in Poznan and the application research of monitoring Chara-dominated lakes. The authors thank Prof. W. Żukowski and Prof. K. Latowski (Adam Mickiewicz University) for the helpful comments on this study.

\section{REFERENCES}

BAnAś B. (2001): Schoenoplectus mucronatus (L.) Palla. Oczeret sztyletowaty. In: R. Kaźmierczakowa, K. Zarzycki (eds). Polska czerwona księga roślin. Paprotniki i rośliny kwiatowe. Polish red data book of plants. Pteridophytes and flowering plants. Instytut Botaniki im. W. Szafera PAN, Instytut Ochrony Przyrody PAN, Kraków: 469-470.

Bilz M., Kell S.P., Maxted N., Lansdown R.V. (2011): European red list of vascular plants. Publications Office of the European Union, Luxembourg.

Borhidi A. (2003): Magyarország Növénytársulásai. Akadémiai Kiadó, Budapest.

BRINK M. (2011): Schoenoplectiella mucronata (L.) J. Jung \& H.K. Choi. [Internet] Record from PROTA4U. Brink, M. \& Achigan-Dako, E.G. (Editors). PROTA (Plant Resources of Tropical Africa/Ressources végétales de l'Afrique tropicale), Wageningen, Netherlands. <http://www.prota4u.org/ search.asp >. [access:23 July 2015].

Casper S.J., Krausch H.D. (1980): Süsswasserflora von Mitteleuropa. Bd. 23. Pteridophyta und Anthophyta. Gustav Fischer Verlag, Stuttgart.

DeBerry D.A., McGoff N., ZinN N.D. (2010): Virginia: an account of Schoenoplectus mucronatus (L.) Palla in Virginia with comments on species introductions in wetland mitigation sites. Castanea 75(4): 503-505.

DierschKe H. (1994): Pflanzensoziologie. Grundlagenund Methoden. Ulmer, Stuttgart.

Fischer A.J., Strong G.L., Shackel K., Mutters R. (2010): Temporary drought can selectively suppress Schoenoplectus mucronatus in rice. Aquatic Botany 92(4): 257-264.

Hultén E. (1958): The amphi-atlantic plants and their phytogeographical connections. Kungliga Svenska Vetenskaps- Akademiens Handlingar Fjarde Serien. Almquist \& Wihsell, Stockholm, 7(1): 1-340.

Jung J., CHOI H.K. (2010): Systematic rearrangement of Korean Scirpus L. s.l. (Cyperaceae) as inferred from nuclear ITS and chloroplast rbcL sequences. Journal of Plant Biology 53: 222-232.

KaźMierczaKowa R., ZarZYCKI K., MireK Z. (2014): Polska czerwona księga roślin. Paprotniki i rośliny kwiatowe. Polish red data book of plants. Pteridophytes and flowering plants. Instytut Ochrony Przyrody PAN, Kraków.
Kornijów R., PęczuŁa W., Lorens B., Ligęza S., Rechulicz J., Kowalczyk-Pecka D. (2002): Shallow Polesie lakes from the view point of the alternative stable states theory. Acta Agrophysica 68: 61-72.

Kornijów R., Rechulicz J., HalKiewicz A. (2003): Brown bullhead (Ictalurus nebulosus Le Sueur) in ichthyofauna of several Polesie Lakes differing in trophic status. Acta Scientiarum Polonorum. Piscaria 2(1): 131-140.

KoтоŃsKA B. (1991): Rośliny naczyniowe Beskidu Małego (polskie Karpaty Zachodnie). Zeszyty Naukowe UJ, Prace Botaniczne 23.

Kruk J., SZymańsKa R. (2011): Nowe stanowisko paproci wodnej - gałuszki kulecznicy Pilularia globulifera w Polsce. A new locality of pillwort Pilularia globulifera in Poland. Chrońmy Przyrodę Ojczystą 67(1): 76-80.

LANSDOWN R.V. (2013): Schoenoplectus mucronatus. The IUCN red list of threatened species. Version 2015.2. <www.iucnredlist.org > . Downloaded on 23 July 2015.

Meusel H., Jäger E., Weinert E. (1965): Vergleichende Chorologie der Zentraleuropäischen Flora. Band 2. Gustav Fischer Verlag, Jena.

Mirek Z., Pięroś-Mirkowa H., Zając A., Zając M. (2002): Flowering plants and pteridophytes of Poland. A checklist. Biodiversity of Poland. Vol. 1 - Krytyczna lista roślin naczyniowych Polski. T. 1. Różnorodność biologiczna Polski. W. Szafer Institute of Botany, Polish Academy of Sciences, Kraków.

NiKolí́ T., Topić J. (2005): Red book of vascular flora of Croatia. Ministry of Culture, State Institute for Nature Protection, Republic of Croatia, Zagreb.

RatyŃsKa H., Wojterska M., Brzeg A. (2010): Multimedialna encyklopedia zbiorowisk roślinnych Polski. CD 1-2. Narodowy Fundusz Ochrony Srodowiska i Gospodarki Wodnej w Warszawie, Warszawa.

Rozmus R. (1974): Nowe stanowisko Schoenoplectus mucronatus (L.) Palla w Polsce. A new locality of Schoenoplectus mucronatus (L.) Palla in Poland. Fragmenta Floristica et Geobotanica 20(2): 131-134.

RozPoRZĄDZENIE Ministra Środowiska $z$ dnia 9 października 2014 r. w sprawie ochrony gatunkowej roślin. Dz.U. 2014, poz. 1409.

Schalow E. (1930): Über ein neues Vorkommen von Scirpus mucronatus L. im östlichen Deutschland. Verhandlungen des Botanischen Vereins der Provinz Brandenburg 72: 129-132.

Schube T. (1903): Die Verbreitung der Gefässpflanzen in Schlesien preussischen und österreichischen Anteils. Druck von R. Nischkowsky, Breslau.

SzCZĘ́śniak E., Rosadziński S., Spatek K., Szymanowski M., Kreitschitz A., KruK J., ŚliwińsKi M., KamiŃSKI R. (2013): Current distribution of Pilularia globulifera L. in Poland: changes of geographical range and habitat preferences. Acta Societatis Botanicorum Poloniae 82(1): 37-46. 
ZająC M. (1989): Flora południowej części Kotliny Oświęcimskiej i Pogórza Śląskiego. Flora of the southern part of the Oświęcim Basin and Silesian Foothills. Zeszyty Naukowe UJ, Prace Botaniczne 19.

ZAJĄC Z., ZAJĄC M. (eds) (2001): Distribution atlas of vascular plants in Poland. Pracownia Chorologii Komputerowej Instytutu Botaniki Uniwersytetu Jagiellońskiego, Kraków.

ZARZYCKI K., SzeląG Z. (2006): Red list of the vascular plants of Poland. In: Z. Mirek, K. Zarzycki, W. Wojewoda, Z. Szeląg (eds). Red list of plants and fungi in Poland. W. Szafer Institute of Botany, Polish Academy of Sciences, Kraków.

Żukowski W. (1969): Studia systematyczne i geograficzne nad podrodziną Cyperoideae w Polsce. Poznańskie Towarzystwo Przyjaciół Nauk. Prace Komisji Biologicznej 33(3): 1-132.

For citation: Rybak M., GąbKa M., Pęczuta W. (2016): A new locality of endangered bog bulrush Schoenoplectiella mucronata (Cyperaceae) in the Eastern Poland. Steciana 20(1): 15-19. doi: 10.12657/steciana.020.003 